\title{
Temperature Dependent Behavior of Isotactic and Atactic Poly(Methacrylic Acid) in the Presence of $\mathrm{MgCl}_{2}$ and $\mathrm{CaCl}_{2}$
}

\author{
Patricija Hriberšek ${ }^{1}$ and Ksenija Kogej ${ }^{1, *}$ \\ ${ }^{1}$ Department of Chemistry and Biochemistry, Faculty of Chemistry and Chemical Technology, \\ University of Ljubljana, SI-1000 Ljubljana, Slovenia \\ *Corresponding author: E-mail: ksenija.kogej@fkkt.uni-lj.si \\ Tel.: 01-4798-538;
}

Received: 11-06-2019

\begin{abstract}
Temperature ( $T$ ) induced nanoparticle formation of isotactic (iPMA) and atactic (aPMA) poly(methacrylic acid) chains is investigated in aqueous solutions in the presence of divalent cations $\left(\mathrm{Mg}^{2+}\right.$ and $\left.\mathrm{Ca}^{2+}\right)$ by $\mathrm{UV}$ spectroscopy, visual observations and pyrene fluorimetry. In aPMA solutions, aggregation and phase separation take place with increasing $T$. The onset of aPMA aggregation (heating) and re-dissolution of the aggregates (cooling) is shifted to lower Ts with increasing ionic strength of the solutions. iPMA associates partly decompose upon heating, but stable nano-sized particles are present at all Ts. Structural characterization of the aggregates was carried out by dynamic and static light scattering measurements at $25^{\circ} \mathrm{C}$. Results revealed that aggregates of both PMAs with $\mathrm{Mg}^{2+}$ ions involve a lot of water and have a rather even mass distribution. This is attributed to strong hydration of $\mathrm{Mg}^{2+}$ ions and their preference towards monodentate binding to carboxylate groups. Differently, $\mathrm{Ca}^{2+}$ ions bind more strongly and in a bidentate manner, they lose the hydration water and form aggregates with several structural elements, depending on chain tacticity.
\end{abstract}

Keywords: Temperature-responsive polymers; poly(methacrylic acid) isomers; atactic; isotactic; divalent cations; intermolecular association

\section{Introduction}

Despite the ubiquitous presence of polyelectrolytes in chemistry, biology and physics, their interactions with numerous species, among those also with oppositely charged and multivalent metal ions, still present one of the most challenging aspects of macromolecule chemistry. These interactions have a significant effect on size, charge and structure of the polymer molecules in solutions, on dynamics of polymer chains, kinetics of eventual phase separation, and furthermore have implications to biological systems, since metal ions perform important functions in biological processes. ${ }^{1-3}$ Among the most common cations found in nature and in living systems are divalent $\mathrm{Mg}^{2+}$ and $\mathrm{Ca}^{2+}$. Since these two ions play a crucial role in stabilizing the structure of many proteins, many studies have been performed on their interactions with macromolecules. ${ }^{1,4-10}$ For example, $\mathrm{Mg}^{2+}$ is responsible for the DNA replication ${ }^{1,5}$ and $\mathrm{Ca}^{2+}$ has a stabilizing function in bones, teeth and shells. ${ }^{111}$ They are both so-called hard ions and prefer to bind to hard ligands containing oxygen, such as carboxylates, carbonyls, water, and hydroxyl groups. ${ }^{1,12}$ However, $\mathrm{Mg}^{2+}$ and $\mathrm{Ca}^{2+}$ each has specific properties that make them different from each other. Apart from small ionic $\left(0.65 \AA^{13}\right)$ and significantly larger hydrated radius $\left(4.76 \AA^{13,14}\right)$, one of the main characteristics of $\mathrm{Mg}^{2+}$ is strong interaction with water molecules leading to a bulky hydration sphere with a hexa-coordinated geometry around this ion. The slow exchange rate of the hydrated water molecules is responsible that $\mathrm{Mg}^{2+}$ ions do not readily lose water molecules. ${ }^{1,4,6,12-18}$ These features of $\mathrm{Mg}^{2+}$ play a crucial role in stabilizing the monodentate binding of $\mathrm{Mg}^{2+}$ to carboxylate group (see Scheme S1 in Supporting Information (SI)). 1,4,12,13,17

$\mathrm{Ca}^{2+}$ has quite different properties in comparison to $\mathrm{Mg}^{2+}$ and therefore participates in different biochemical processes. ${ }^{11,13}$ Its ionic radius $\left(0.99^{13}\right)$ is considerably larger in comparison to $\mathrm{Mg}^{2+}$ and this leads to significant flexibility in the coordination number of its complexes with various ligands. The water coordination numbers for $\mathrm{Ca}^{2+}$ range from 6 to 8 , but also up to 12 is possible, which leads to irregular geometry of the ion's coordination sphere. ${ }^{1,11-13} \mathrm{Hy}$ drated radius of $\mathrm{Ca}^{2+}$ thus depends on the coordination 
number, but is always smaller than that of $\mathrm{Mg}^{2+}$. For coordination numbers $6-8$, the hydrated radius is $2.95 .{ }^{13}$ These properties cause that $\mathrm{Ca}^{2+}$ can easily lose water molecules from its hydration sphere. ${ }^{13,15,16}$ Its complexes, in which bidentate binding prevails, ${ }^{17}$ are therefore classified as 'dry'. There are two types of bidentate binding of $\mathrm{Ca}^{2+}$ to carboxylate groups: chelating bidentate and bridging bidentate binding (see Scheme S1). In chelating coordination, one central $\mathrm{Ca}^{2+}$ ion is bound to two oxygen atoms of one carboxyl group, whereas in bridging coordination $\mathrm{Ca}^{2+}$ bridges two different carboxyl groups via their oxygen atoms. ${ }^{19}$

Interactions of macromolecules and counterions are important also in the (bio)technological, industrial, and pharmaceutical fields, where synthetic polymers are more commonly used. ${ }^{2,3}$ For example, poly(acrylic acid) is a promising candidate for controlling water hardness ${ }^{20}$ and poly(methacrylic acid) (PMA) is widely studied due to its $\mathrm{pH}$ - and temperature dependent behavior, ${ }^{21-24}$ which is very appropriate in targeted drug delivery. ${ }^{25}$ In the case of PMA, chain tacticity brings in qualitatively different solution behavior. For example, the atactic form (aPMA) is known to form intermolecular associates in dilute aqueous solutions ${ }^{26}$ and gels in concentrated solutions upon heating, ${ }^{22-24,27,28}$ whereas the isotactic form (iPMA) associates upon cooling. ${ }^{26,28,30}$ These findings are attributed to different distribution of polar (carboxyl) and nonpolar (methyl) groups on aPMA and iPMA chains and consequently within the associates. The favorable isotactic arrangement of carboxyl groups on iPMA favors strong hydrogen bonding between neighboring chains and exposes the methyl groups towards the polar solvent (water), leading to insolubility of unionized iPMA in water. Increasing the temperature destroys the $\mathrm{H}$-bonds, the associates decompose and consequently carboxyl groups become exposed to water. This is different when the distribution of functional groups is irregular, such as in aPMA. In this case, hydrogen bonding is much less advantageous. The mostly free carboxyl groups are exposed to water and the methyl groups can effectively hide from the polar aqueous environment by forming associates with a hydrophobic core. Increasing the temperature would lead to exposure of these methyl groups to water, which is clearly unfavorable. As a result, the polymer chains first form intermolecular associates and finally precipitate from solution at elevated temperatures. Our previous results show that the added simple salt, in particular the cation charge, affects the temperature at which association takes place, either by heating (aPMA) or by cooling (iPMA). ${ }^{28}$

The main focus of this paper is to compare the effect of biologically relevant divalent $\mathrm{Mg}^{2+}$ and $\mathrm{Ca}^{2+}$ cations on the temperature-dependent association of iPMA and aPMA chains in aqueous solutions. For this purpose, we first carry out UV spectroscopy measurements supported by visual observations in the temperature range between 0 and $95^{\circ} \mathrm{C}$ to clarify the effect of polymer tacticity on the association process. To identify the role that the specific nature of $\mathrm{Mg}^{2+}$ and $\mathrm{Ca}^{2+}$ plays in the interaction with carboxylate groups on PMA isomers, fluorescence measurements using pyrene as a polarity probe are used. Finally, the molecular characteristics of the associates are determined by dynamic (DLS) and static light scattering (SLS), which are further supported by $\mathrm{pH}$ measurements, both carried out at $25^{\circ} \mathrm{C}$.

\section{Experimental}

\section{1. Materials}

The aPMA sample (product number P2419-MAA) with the weight $\left(M_{\mathrm{w}}\right)$ and number average molar masses $\left(M_{\mathrm{n}}\right)$ of $M_{\mathrm{w}}=159900 \mathrm{~g} \mathrm{~mol}^{-1}$ and $M_{\mathrm{n}}=123000 \mathrm{~g} \mathrm{~mol}^{-1}$ and a polydispersity index (PDI) of PDI $=1.3$ was purchased from Polymer Source Inc (Montreal, QC, Canada). iPMA was obtained by acidic hydrolysis of its ester form, isotactic poly(methylmetacrylate) (iPMMA), which was synthesized following the procedure reported in the litera$\operatorname{ture}^{29,30}$ at the Catholic University of Leuven. Detailed description of hydrolysis and further purification of iPMA was described previously. ${ }^{29,31}$ The molecular characteristics of the starting iPMMA were the following: the triad content or tacticity was $94 \%$ of isotactic, $4 \%$ of syndiotactic, and $2 \%$ of atactic triads, $M_{\mathrm{w}}=138000 \mathrm{~g} \mathrm{~mol}^{-1}, M_{\mathrm{n}}=30000 \mathrm{~g} \mathrm{~mol}^{-1}$, and PDI $=4.6$. After hydrolysis and purification, the $M_{\mathrm{w}}$ and PDI $\left(M_{\mathrm{w}}=69500 \mathrm{~g} \mathrm{~mol}^{-1}\right.$ and PDI $\left.=3\right)$ were determined by size exclusion chromatography, and the degree of hydrolysis (> 98\%) was determined from the ${ }^{1} \mathrm{H}$ nuclear magnetic resonance spectrum of the sample in $\mathrm{D}_{2} \mathrm{O}$.

$\mathrm{MgCl}_{2}$ (> 98\%; Sigma Aldrich, St. Louis, Missouri, USA) and $\mathrm{CaCl}_{2}$ (in the form $\mathrm{CaCl}_{2} \times 2 \mathrm{H}_{2} \mathrm{O}$; pro analysis, Merck KGaA, Darmstadt, Germany) were used to prepare stock salt solutions in water. The exact concentration of salts $\left(c_{\mathrm{s}}\right)$ was determined by potentiometric titration using a standardized $\mathrm{AgNO}_{3}$ solution. Pyrene (optical grade) for fluorimetric measurements was purchased from Aldrich (Darmstadt, Germany). The saturated solutions of pyrene in aqueous $\mathrm{MgCl}_{2}$ and $\mathrm{CaCl}_{2}$ were prepared as reported previously. ${ }^{32,33}$

\section{2. Preparation of Solutions}

Stock solution of aPMA was prepared at a degree of neutralization $\left(\alpha_{\mathrm{N}}\right) \alpha_{\mathrm{N}}=0$ by dissolving the dry polymer in water. After one day of stirring, the solution was filtered through $0.45 \mu \mathrm{m}$ Millex HV filter and the exact polymer concentration $\left(c_{\mathrm{m}}\right.$, in $\left.\mathrm{g} \mathrm{L}^{-1}\right)$ was determined by potentiometric titration with a standardized $\mathrm{NaOH}$ solution.

The iPMA does not dissolve in water at $\alpha_{\mathrm{N}}=0 .{ }^{29,34,35}$ Therefore, the iPMA stock solution was prepared at a higher $\alpha_{\mathrm{N}}(>0.8)$ to ensure that the polyacid was completely dissolved. A calculated volume of $1 \mathrm{M} \mathrm{NaOH}$ was slowly added to the iPMA suspension in water under continuous stirring to obtain the desired $\alpha_{\mathrm{N}}$ value. The dissolution process at 
room temperature was slow. The iPMA suspension was stirred for several days with occasional heating to $\sim 50{ }^{\circ} \mathrm{C}$, which accelerated the dissolution. When the polymer was visually dissolved, the solution was filtered through $0.45 \mu \mathrm{m}$ Millex HV filter and the exact $\alpha_{\mathrm{N}}$ and $c_{\mathrm{m}}$ values were determined by potentiometric titration, first with $0.1 \mathrm{M} \mathrm{NaOH}$ in the direction of increasing $\alpha_{\mathrm{N}}$ (to determine the concentration of the still protonated $\mathrm{COOH}$ groups) and then with 0.1 $\mathrm{M} \mathrm{HCl}$ in the direction of decreasing $\alpha_{\mathrm{N}}$ (to determine the total concentration of carboxyl groups).

Due to differences in solubility, different procedures were used also for the preparation of aPMA and iPMA solutions with added $\mathrm{MgCl}_{2}$ and $\mathrm{CaCl}_{2}$. Solutions of aPMA with a desired salt concentration $\left(c_{\mathrm{s}}\right)$ were prepared by adding a calculated volume of concentrated salt solutions to the aPMA stock solution and diluting the solution with triple distilled water to adjust the concentration of aPMA and the ionic strength $(I)$ to the desired values. For all the measurements with aPMA, $\alpha_{\mathrm{N}}=0, c_{\mathrm{m}}=2 \mathrm{~g} \mathrm{~L}^{-1}$ (or in moles of $\mathrm{COOH}$ groups per volume, designated as $c_{\mathrm{p}}, c_{\mathrm{p}}=$ $0.023 \mathrm{~mol} \mathrm{~L}^{-1}$ ), and the concentration of $\mathrm{MgCl}_{2}$ and $\mathrm{CaCl}_{2}$ was $c_{\mathrm{s}}=0.0333$ and $0.0667 \mathrm{~mol} \mathrm{~L}^{-1}$, which corresponds to $I=0.1$ and $0.2 \mathrm{~mol} \mathrm{~L}^{-1}$, respectively (these data are collected in Table S1). UV and $\mathrm{pH}$ measurements with aPMA were performed also at higher $I$ (or $c_{\mathrm{s}}$ ) values, i.e. in the range $I=0.1-0.5 \mathrm{~mol} \mathrm{~L}^{-1}$.

For the preparation of iPMA solutions with the lowest possible $\alpha_{\mathrm{N}}$, at which the polyacid was still soluble, a calculated amount of $0.1 \mathrm{M} \mathrm{HCl}$ was gradually added to the stock solution with $\alpha_{\mathrm{N}}>0.8$, which resulted in some $\mathrm{NaCl}$ in solution. The $\mathrm{NaCl}$ was removed by dialysis using dialysis membranes Float-A-Lyzer G2 with a molecular weight cut-off $\mathrm{MWCO}=3.5-5 \mathrm{kDa}$. Finally, calculated amounts of concentrated $\mathrm{MgCl}_{2}$ or $\mathrm{CaCl}_{2}$ solutions and water were added slowly and under continuous stirring to adjust $I$ and $c_{\mathrm{p}}$ to the desired final values, so as in the case of aPMA. The final $I$ values were 10 times lower in comparison to aPMA, because iPMA precipitated from solutions with $I=0.1 \mathrm{~mol} \mathrm{~L}^{-1}$ in the presence of the studied divalent cations. For both, $\mathrm{MgCl}_{2}$ and $\mathrm{CaCl}_{2}, I$ was 0.01 (or $c_{\mathrm{s}}=0.0033 \mathrm{~mol} \mathrm{~L}^{-1}$ ) and $0.02 \mathrm{~mol} \mathrm{~L}^{-1}$ (or $c_{\mathrm{s}}=0.0067 \mathrm{~mol}$ $\left.\mathrm{L}^{-1}\right)$ and $\alpha_{\mathrm{N}}$ was 0.2 . In the case of $\mathrm{MgCl}_{2}$, the iPMA solution with $\alpha_{\mathrm{N}}=0.2$ and $I=0.02 \mathrm{~mol} \mathrm{~L}^{-1}$ was stable (no phase separation occurred). However, in the case of $\mathrm{CaCl}_{2}$, $\alpha_{\mathrm{N}}$ in iPMA solution with $I=0.02 \mathrm{~mol} \mathrm{~L}^{-1}$ could not be reduced to $\alpha_{\mathrm{N}}=0.2$, because the solution became opaque when $\alpha_{\mathrm{N}}$ was decreased from $\alpha_{\mathrm{N}}>0.8$ to $\alpha_{\mathrm{N}}=0.63$ and remained cloudy even after prolonged stirring. This solution was therefore studied at $\alpha_{\mathrm{N}}=0.63$. All $I, c_{\mathrm{s}}$, and $\alpha_{\mathrm{N}}$ values for iPMA solutions are reported in Table S1.

\section{3. Methods}

\section{3. 1. Visual Observations}

In order to obtain visual information about temperature-dependent aggregation of a- and iPMA chains in aqueous solutions, samples were kept in cuvettes and equilibrated at different temperatures $(T)(T=15,25,45,55,65$, 75,85 and $95^{\circ} \mathrm{C}$ ) in a Julabo circulator. aPMA in $\mathrm{MgCl}_{2}$ and $\mathrm{CaCl}_{2}$ precipitated on a macroscopic scale during heating. The samples were photographed and the photographs are presented in Tables S2 and S3. For iPMA, only pictures at $25^{\circ} \mathrm{C}$ are shown (Table S4), because the solutions were transparent in the whole temperature range. Photographs of iPMA in $\mathrm{CaCl}_{2}$ with $I=0.02 \mathrm{~mol} \mathrm{~L}^{-1}$ and $\alpha_{\mathrm{N}}=0.63$ (not shown) resembled the case of aPMA at $75^{\circ} \mathrm{C}$.

\section{3. 2. UV Measurements}

The UV absorbance $(A)$ was recorded with a UV-Vis spectrophotometer Cary BIO 100 (Varian, Australia) at a wavelength $\lambda=280 \mathrm{~nm}$ in the temperature range between 0 and $95^{\circ} \mathrm{C}$. To avoid condensation on the cuvette walls, measurements were carried out by blowing dry nitrogen around the cuvette. Samples were degassed prior to measurements. The heating and cooling rate programs were different for a- and iPMA solutions and are reported in Table S5.

\section{3. 3. Fluorimetric Measurements}

Fluorimetric measurements were performed by using pyrene as the external fluorophore. The fluorescence emission spectra of pyrene were recorded on a PerkinElmer model LS-100 luminescence spectrometer in the direction of increasing temperature (from 15 to $95{ }^{\circ} \mathrm{C}$ ) with a step of $10{ }^{\circ} \mathrm{C}$, also under nitrogen flow similar to UV measurements. The excitation light wavelength was $330 \mathrm{~nm}$, the recording speed was $100 \mathrm{~nm} \mathrm{~min}{ }^{-1}$, and 20 emission spectra were collected in the wavelength region $350-450 \mathrm{~nm}$ and averaged. From the averaged spectra, the ratio of intensities of the first $\left(I_{1}\right)$ and the third $\left(I_{3}\right)$ vibrational peak in the emission spectrum of pyrene or socalled pyrene polarity ratio $\left(I_{1} / I_{3}\right)$ was calculated.

\section{3. 4. Light Scattering}

In order to obtain the information on size and structure of aPMA and iPMA associates in $\mathrm{MgCl}_{2}$ and $\mathrm{CaCl}_{2}$ solutions, dynamic (DLS) and static light scattering (SLS) measurements were performed with the 3D-DLS-SLS cross-correlation spectrometer from LS Instruments $\mathrm{GmbH}$ (Fribourg, Switzerland). The measurements were carried out only at $25^{\circ} \mathrm{C}$. The source of incident light was the He-Ne laser with a wavelength $\lambda_{0}=632.8 \mathrm{~nm}$. Intensity of scattered light was collected in the angular range between $40^{\circ}$ and $150^{\circ}$ with a step of $10^{\circ}$ after keeping the samples at $25^{\circ} \mathrm{C}$ for $30 \mathrm{~min}$. At each angle, five correlation functions were collected and averaged. For processing the measured correlation functions, CONTIN analysis was used. Prior to light scattering (LS) measurements, all aPMA and iPMA solutions were filtered through hydro- 
philic and low protein binding Millex-HV filters (diameter $13 \mathrm{~mm}$, pore size $0.45 \mu \mathrm{m}$ ) directly into the sealable dustfree cylindrical quartz LS sample cells. LS measurements were performed 3 days after filtration. Due to opacity, iPMA solution in $0.0067 \mathrm{~mol} \mathrm{~L}^{-1} \mathrm{CaCl}_{2}\left(I=0.02 \mathrm{~mol} \mathrm{~L}^{-1}\right.$ and $\alpha_{\mathrm{N}}=0.63$; see above) was studied without being filtered. Note that the $3 \mathrm{D}$ cross-correlation technique was designed especially for the characterization of such strongly turbid samples. ${ }^{36}$ After 2 weeks two phases were observed in the cuvette in this case. The one at the bottom was more turbid than the upper one. By changing the height of the cuvette in the decalin bath, we were able to perform the LS characterization of both phases separately.

LS experiments identified two (in some cases three) populations of particles in iPMA and aPMA solutions (see examples of calculated hydrodynamic radii $\left(R_{\mathrm{h}}\right)$ distributions in Figure $\mathrm{S} 1)$. The $R_{\mathrm{h}}$ values of smaller particles $\left(R_{\mathrm{h}}<\right.$ $10 \mathrm{~nm}$, assigned to individual chains, and $10 \mathrm{~nm}<R_{\mathrm{h}}<20$ $\mathrm{nm}$, assigned to small pre-associates; not reported) did not depend on the angle. We were interested in the $R_{\mathrm{h}}$ values of larger particles (70-200 $\mathrm{nm}$ ), which were assigned to inter-chain associates and designated as $R_{\mathrm{h}, \text { ass }}$. Their values depended considerably on the angle of observation. For further calculations, the $R_{\mathrm{h} \text {,ass }}$ values at $\theta=0^{\circ}$ were obtained by extrapolation of the measured $R_{\mathrm{h} \text {,ass }}$ to zero angle. Due to large size of the associates, their radius of gyration $\left(R_{\mathrm{g}, \mathrm{ass}}\right)$ could be determined from the angular dependency of the LS intensity following the procedures reported previously. ${ }^{37-39}$ From $R_{\mathrm{h} \text {,ass }}$ at $\theta=0^{\circ}$ and $R_{\mathrm{g}, \text { ass }}$, the shape parameter $(\rho)$ was calculated as $\rho=R_{\mathrm{g} \text {,ass }} / R_{\mathrm{h} \text {,ass }}$. This parameter is often used to characterize mass distribution within the scattering particles. ${ }^{37,38}$ All further details of LS data evaluation were reported previously. ${ }^{37-40}$

\subsection{5. $\mathrm{pH}$ Measurements}

The $\mathrm{pH}$ values of the samples were measured by using the combined glass micro-electrode from Mettler Toledo (type InLab ${ }^{\circledR} 423$; Schwerzenbach, Switzerland) and the Iskra pH meter model MA 5740 (Ljubljana, Slovenia).

\section{Results and Discussion}

\section{1. Temperature Dependent Behavior of iPMA and aPMA in the Presence of $\mathrm{MgCl}_{2}$ and $\mathrm{CaCl}_{2}$}

\section{1. 1. UV Spectroscopy and Visible Observations}

In Figure 1, $A$ is presented as a function of temperature for aPMA $\left(\alpha_{\mathrm{N}}=0\right)$ solutions with $I=0.1 \mathrm{~mol} \mathrm{~L}^{-1}$ and for iPMA $\left(\alpha_{\mathrm{N}}=0.2\right)$ solutions with $I=0.01 \mathrm{~mol} \mathrm{~L}^{-1}$ in the presence of both, $\mathrm{MgCl}_{2}$ and $\mathrm{CaCl}_{2}$. In addition, measurements for aPMA at higher $I\left(=0.2-0.5 \mathrm{~mol} \mathrm{~L}^{-1}\right)$ are shown in Figure 2. The data demonstrate that aqueous aPMA solutions with added $\mathrm{MgCl}_{2}$ and $\mathrm{CaCl}_{2}$ behave as polymer mixtures with so-called lower critical solution temperature (LCST) behavior. The LCST behavior (phase separation induced by heating) is inferred from the fact that UV absorbance is close to zero at low temperatures (below 70 and 80 ${ }^{\circ} \mathrm{C}$ in $\mathrm{CaCl}_{2}$ and $\mathrm{MgCl}_{2}$, respectively; Figure 1b) and steeply increases at high temperatures. Strong increase in $A$ indicates the formation of larger particles in solution, which is ultimately followed by phase separation of the polymer-rich phase (see visual observations reported below). Clearly, the increase in $A$ is more pronounced in the presence of $\mathrm{Ca}^{2+}$ ions. For the aPMA- $\mathrm{CaCl}_{2}$ solution, a plateau in $A$ is reached between 80 and $90^{\circ} \mathrm{C}$, followed by a fall as $T$ approaches $95^{\circ} \mathrm{C}$. We anticipate that this final drop in $A$ is a consequence of the fact that the aPMA precipitate in the presence of $\mathrm{CaCl}_{2}$ is effectively removed from the solution by settling down to the bottom of the cuvette, whereas it still fills the whole cuvette in the $\mathrm{MgCl}_{2}$ solution at this $I\left(=0.1 \mathrm{~mol} \mathrm{~L}^{-1}\right.$; for more details see photographs in Table S2). The LCST for aPMA- $\mathrm{CaCl}_{2}$ solution clearly appears at lower $T$ s in comparison with that in aPMA- $\mathrm{MgCl}_{2}$ solution (see the LCST values reported in Table S6 and the method for their determination shown in Figure S2).

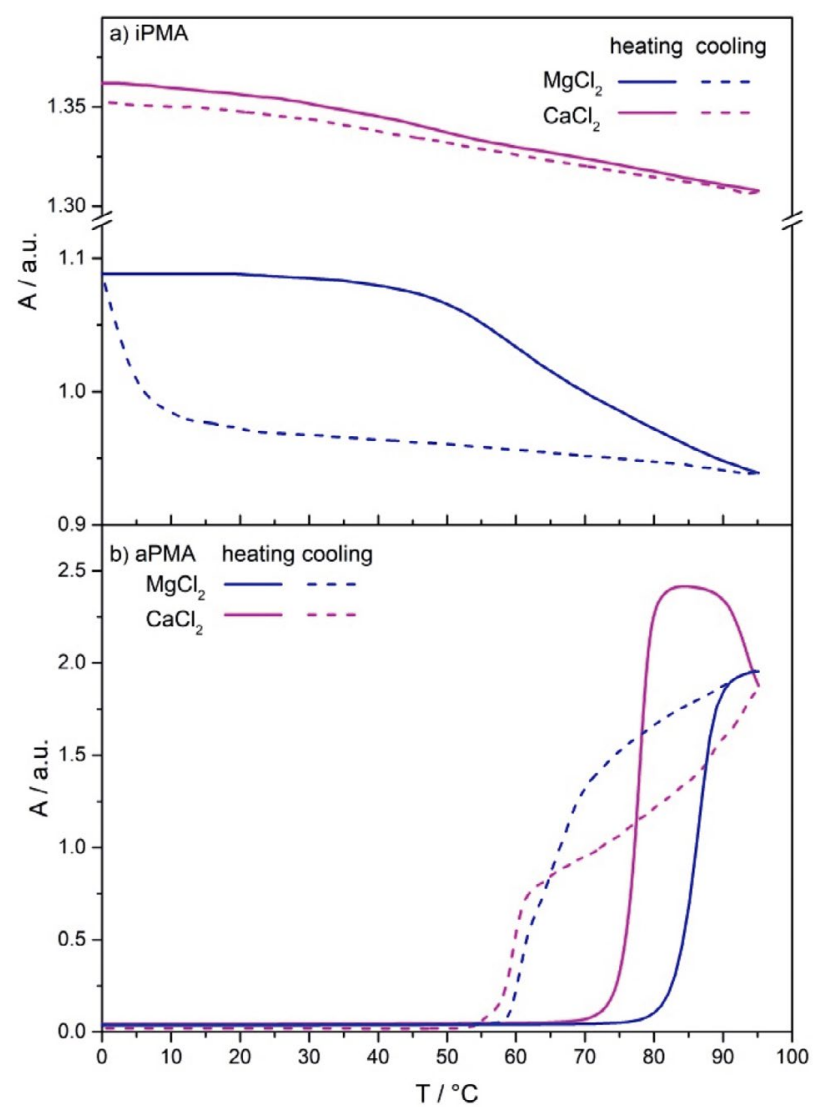

Figure 1. UV absorbance at $280 \mathrm{~nm}$ as a function of temperature for a) iPMA $\left(c_{\mathrm{p}}=0.022 \mathrm{~mol} \mathrm{~L}^{-1}, \alpha_{\mathrm{N}}=0.20\right)$ in $\mathrm{MgCl}_{2}$ and $\mathrm{CaCl}_{2}$ with $I$ $=0.01 \mathrm{~mol} \mathrm{~L}^{-1}$, and for b) aPMA $\left(c_{\mathrm{p}}=0.023 \mathrm{~mol} \mathrm{~L}^{-1}, \alpha_{\mathrm{N}}=0\right)$ in $\mathrm{MgCl}_{2}$ and $\mathrm{CaCl}_{2}$ with $I=0.1 \mathrm{~mol} \mathrm{~L}$. Heating (solid lines) and cooling (dashed lines) were performed according to the temperature programs reported in Table S5. 
During cooling the aPMA- $\mathrm{MgCl}_{2}$ solution back to the initial temperature, the absorbance first decreases gradually and then drops steeply to 0 at lower temperatures (below approximately $60{ }^{\circ} \mathrm{C}$ ) as compared to the heating direction. Meanwhile, the initial drop in $A$ upon cooling the aPMA-CaCl solution is steeper, but reaches zero at approximately the same temperature (at around $58^{\circ} \mathrm{C}$ ) as in $\mathrm{MgCl}_{2}$ solution. The drop in $A$ to zero indicates that aPMA aggregates, which form in the presence of $\mathrm{MgCl}_{2}$ and $\mathrm{CaCl}_{2}$ upon heating, disintegrate upon cooling. We conclude that $\mathrm{Mg}^{2+}$ and $\mathrm{Ca}^{2+}$ cations induce reversible association of aPMA chains at elevated temperatures. These findings are in agreement with our recent report on intermolecular association of aPMA chains in the presence of cations with increasing charge. ${ }^{28}$ The occurrence of the aPMA rich phase (the turbid part that eventually forms a precipitate) in the $\mathrm{CaCl}_{2}$ solution is similar to that in $\mathrm{LaCl}_{3}{ }^{28}$ This is not surprising, since both cations $\left(\mathrm{Ca}^{2+}\right.$ and $\mathrm{La}^{3+}$ ) are known to bind to carboxylate groups in a bidentate manner. ${ }^{19}$ The $\mathrm{La}^{3+}$ cations are also recognized as $\mathrm{Ca}^{2+}$ analogs in living systems and can thus act as substitutes of $\mathrm{Ca}^{2+}$ in many proteins and cell membranes. ${ }^{41-43}$ However, in the case of aPMA the presence of trivalent $\mathrm{La}^{3+}$ ions at $I$ $=0.1 \mathrm{~mol} \mathrm{~L}^{-1}$ induces irreversible precipitation from solution (no re-dissolution takes place upon cooling), whereas $\mathrm{Ca}^{2+}$ precipitates re-dissolve at the same $I$.

Visual observations for aPMA $\left(\alpha_{\mathrm{N}}=0\right)$ solutions are in good agreement with the UV results (see photographs presented in Table S2 for the heating and in Table S3 for the cooling direction). When temperature increases above $75^{\circ} \mathrm{C}$, aPMA solutions in $\mathrm{MgCl}_{2}$ and $\mathrm{CaCl}_{2}$ first become turbid. Fine flakes of precipitated aPMA are formed in the presence of $\mathrm{MgCl}_{2}$, which do not readily settle down (the solution remains turbid). In $\mathrm{CaCl}_{2}$ solutions, on the other hand, the initial turbidity is considerably more pronounced (see for example the photograph taken at $85^{\circ} \mathrm{C}$,
Table S2). The precipitate, which subsequently forms in the aPMA- $\mathrm{CaCl}_{2}$ system with further heating to $95^{\circ} \mathrm{C}$, finally settles to the bottom of the cuvette or is partially stuck to the glass wall. This explains the plateau in $A$ values in aPMA- $\mathrm{CaCl}_{2}$ solution at $80-90{ }^{\circ} \mathrm{C}$ (maximum turbidity) and their steep drop towards $95^{\circ} \mathrm{C}$ (partial removal of the precipitate from solution).

The LCST values for aPMA in the presence of $\mathrm{MgCl}_{2}$ and $\mathrm{CaCl}_{2}$ were determined in a broader range of $I$ values (up to $0.5 \mathrm{~mol} \mathrm{~L}^{-1}$ ). Heating of aPMA- $\mathrm{MgCl}_{2}$ solution at higher $I\left(>0.1 \mathrm{~mol} \mathrm{~L}^{-1}\right)$ leads to a similar plateau and a drop in $A$ values as highlighted above for $\mathrm{CaCl}_{2}$ solution for all $I$ (c.f. Figure 2). With increasing $I$, the rise in $A$ shifts to lower LCSTs, whereas the plateau shifts to higher $A$ due to higher turbidity and more extensive precipitation of aPMA from solutions at higher $\mathrm{MgCl}_{2}$ concentration. An-

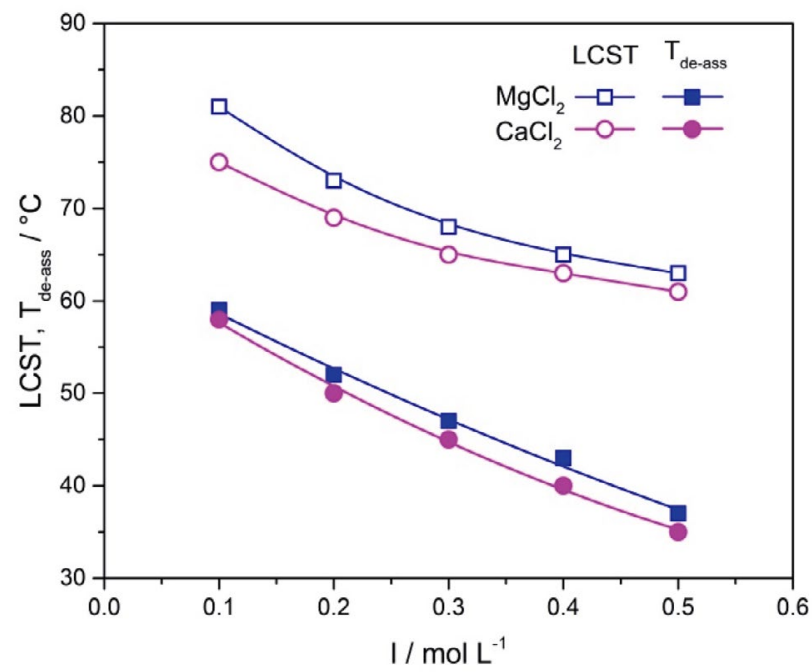

Figure 3. The dependences of LCST and $T_{\text {de-ass }}$ on ionic strength (I) for aPMA $\left(c_{\mathrm{p}}=0.023 \mathrm{~mol} \mathrm{~L}^{-1}, \alpha_{\mathrm{N}}=0\right)$ in $\mathrm{MgCl}_{2}$ and in $\mathrm{CaCl}_{2}$ solutions.

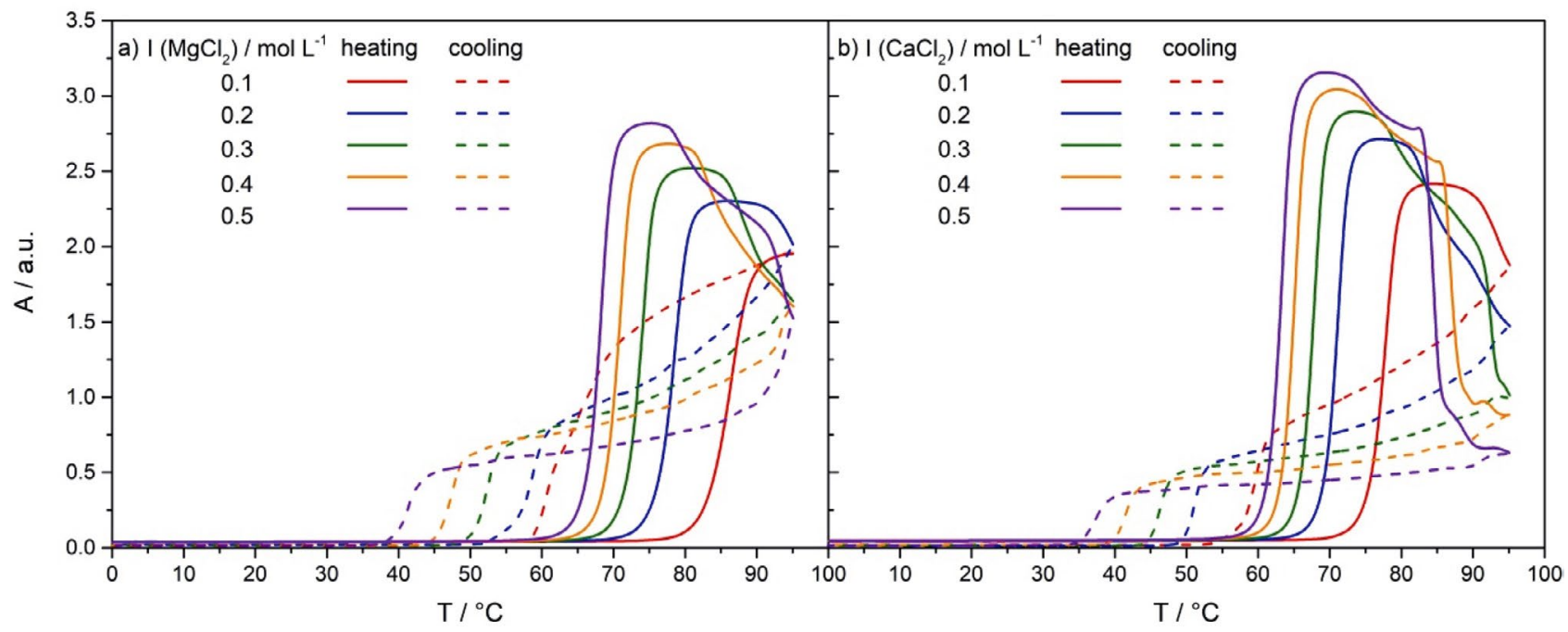

Figure 2. UV absorbance at $280 \mathrm{~nm}$ as a function of temperature for aPMA $\left(c_{\mathrm{p}}=0.023 \mathrm{~mol} \mathrm{~L}^{-1}, \alpha_{\mathrm{N}}=0\right)$ in a) $\mathrm{MgCl}_{2}$ and b) $\mathrm{CaCl}_{2}$ solutions with $I=$ $0.1,0.2,0.3,0.4$ and $0.5 \mathrm{~mol} \mathrm{~L}^{-1}$. The heating (solid lines) and cooling (dashed lines) were performed with a rate of $1^{\circ} \mathrm{C} \mathrm{min}{ }^{-1}$. 
other important observation is that upon cooling the plateau, and consequently the associated critical temperature of de-association, designated as $T_{\text {de-ass }},{ }^{28}$ also shift to lower temperatures with increasing $I$. A strong hysteresis is clearly seen in the plots in Figure 2, indicating that $T_{\text {de-ass }}$ is considerably lower than LCST (see $T_{\text {de-ass }}$ and LCST values reported in Table S6 and plotted in Figure 3).

Similar behavior is observed also for aPMA in the presence of $\mathrm{CaCl}_{2}$. Again, a strong hysteresis is detected along the heating and cooling paths. Nevertheless, some key differences between $\mathrm{MgCl}_{2}$ and $\mathrm{CaCl}_{2}$ solutions can be extracted from these plots. During heating, the plateau in $A$ reaches higher values when $\mathrm{Ca}^{2+}$ cations are present, which means that these divalent cations induce more extensive association and consequently more extensive precipitation of aPMA from the solution in comparison to $\mathrm{Mg}^{2+}$ cations. This can be inferred also from a much steeper drop in $A$ towards the end of the heating cycle in $\mathrm{CaCl}_{2}$ solutions (compare Figure 2b with Figure 2a). In agreement with this, the $T_{\mathrm{de} \text {-ass }}$ and in particular the LCST values, are lower for aPMA in $\mathrm{CaCl}_{2}$, suggesting a more effective intermolecular association of aPMA induced by $\mathrm{Ca}^{2+}$ ions. However, in the case of both divalent chlorides, the LCST and $T_{\text {de-ass }}$ decrease with increasing $I$. Interestingly, $T_{\text {de-ass }}$ approaches body temperature at the highest ionic strength of $0.5 \mathrm{~mol} \mathrm{~L}^{-1}\left(T_{\text {de-ass }}=35\right.$ and $37^{\circ} \mathrm{C}$ in $\mathrm{CaCl}_{2}$ and $\mathrm{MgCl}_{2}$, respectively). From the obtained results we can conclude that changing $I$ of the solutions strongly affects the LCST and $T_{\text {de-ass }}$ values for aPMA in aqueous $\mathrm{MgCl}_{2}$ and $\mathrm{CaCl}_{2}$ solutions, in spite of the fact that the aPMA chain is almost uncharged at $\alpha_{\mathrm{N}}=0$.

The opposite effect of temperature is found for the iPMA isomer as demonstrated by the plot of UV absorbance in Figure 1a. It should be emphasized right from the start that $\alpha_{\mathrm{N}}(=0.2)$ is not negligible in the iPMA case, which puts electrostatic interactions at the forefront in this case. In contrast to aPMA $\left(\alpha_{\mathrm{N}}=0\right)$, the UV absorbance is high in iPMA $\left(\alpha_{N}=0.2\right)$ solutions at low temperatures and starts to decrease at higher temperatures, but never drops to zero, so as is the case with aPMA. This is most clearly seen for the iPMA solution with added $\mathrm{MgCl}_{2}$ : $A$ is roughly constant up to $40^{\circ} \mathrm{C}$ and starts to decrease more steeply above $50^{\circ} \mathrm{C}$, but does not drop below $A \approx 0.95$ even when approaching $95^{\circ} \mathrm{C}$. In the presence of $\mathrm{CaCl}_{2}$, the measured $A$ values are even higher $(A \approx 1.3-1.35)$, suggesting that the concentration and/or size of the iPMA associates are larger than in $\mathrm{MgCl}_{2}$ solution. In addition, no significant drop in $A$ values can be identified from the curves for iPMA in $\mathrm{CaCl}_{2}$ and the hysteresis is almost absent, which suggests stronger interactions and different kinetics of the association process as compared to $\mathrm{MgCl}_{2}$. However, by inspecting the enlarged plot for iPMA- $\mathrm{CaCl}_{2}$ solution (Figure S3) we see that the trend in $A$ values is similar to the one in $\mathrm{MgCl}_{2}$ or in other chlorides. ${ }^{28}$ This type of behavior of aqueous iPMA solutions was previously ascribed to so-called upper critical solution temperature (UCST) behavior, denoting polymer mixtures where phase separation (or merely association) is achieved upon cooling. ${ }^{28}$ The high $A$ values in iPMA $\left(\alpha_{\mathrm{N}}=0.2\right)$ solutions with added $\mathrm{MgCl}_{2}$ and $\mathrm{CaCl}_{2}$ are attributed to the presence of intermolecular associates that are abundant in these solutions in the whole temperature range ( $A$ stays high even at 95 ${ }^{\circ} \mathrm{C}$ ). Similar to these observations, it was found previously that iPMA associates are stable in the whole temperature range in aqueous solutions with added trivalent $\mathrm{La}^{3+}$ ions, however they largely decomposed upon heating in the presence of monovalent $\mathrm{Na}^{+}$ions. ${ }^{28}$ This again indicates the important role of electrostatics (counterion charge) in intermolecular association of iPMA $\left(\alpha_{N}=0.2\right)$ chains.

Visual observations of iPMA solutions show that, in spite of high absorbance, no macroscopic phase separation occurs in iPMA $\left(\alpha_{\mathrm{N}}=0.2\right)$ solutions at $I=0.01 \mathrm{~mol} \mathrm{~L}^{-1}$ (therefore only the photograph at $25^{\circ} \mathrm{C}$ is presented in $\mathrm{Ta}$ ble S4), indicating that iPMA associates are formed on a mesoscopic scale, as already established for iPMA solutions with mono- and trivalent cations under the same conditions (i.e. at $\left.I=0.01 \mathrm{~mol} \mathrm{~L}^{-1}\right) .{ }^{28}$ The iPMA $\left(\alpha_{\mathrm{N}}=0.2\right)$ system is, however, very sensitive to salt concentration as the polymer precipitates from solution when $I$ exceeds $0.01 \mathrm{~mol} \mathrm{~L}^{-1}$ (see Experimental and discussion below). Again, the relatively high charge of the iPMA chain plays the key role here.

\section{1. 2. Fluorescence Measurements}

Pyrene fluorescence measurements were used to follow the micropolarity of the aggregates' interior in aPMA and iPMA solutions. It is expected that pyrene, as a very hydrophobic molecule, would solubilize inside the aggregates if they are composed of a non-polar core. It is wellknown that aPMA chains at low $\alpha_{\mathrm{N}}$ adopt a compact con-

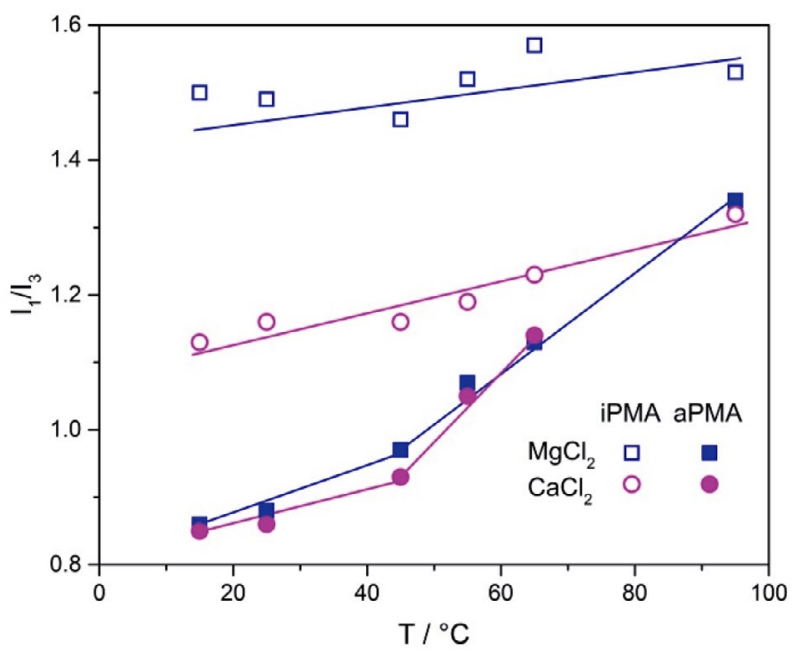

Figure 4. Temperature dependence of the pyrene polarity ratio $\left(I_{1} /\right.$ $\left.I_{3}\right)$ for iPMA $\left(c_{\mathrm{p}}=0.022 \mathrm{~mol} \mathrm{~L}^{-1}, \alpha_{\mathrm{N}}=0.20\right)$ in $\mathrm{MgCl}_{2}$ and $\mathrm{CaCl}_{2}$ solutions with $I=0.01 \mathrm{~mol} \mathrm{~L}^{-1}$ and for aPMA $\left(c_{\mathrm{p}}=0.023 \mathrm{~mol} \mathrm{~L}^{-1}\right.$, $\left.\alpha_{\mathrm{N}}=0\right)$ in $\mathrm{MgCl}_{2}$ and $\mathrm{CaCl}_{2}$ solutions with $I=0.1 \mathrm{~mol} \mathrm{~L}^{-1}$. 
formation with hydrophobic methyl groups forming the interior and offering a suitable solubilization site for pyrene. We were interested in how the tacticity and added divalent metal ions affect the polarity of microenvironment in aPMA $\left(\alpha_{\mathrm{N}}=0\right)$ and iPMA $\left(\alpha_{\mathrm{N}}=0.2\right)$ solutions.

The emission spectra of pyrene for both PMA isomers in $\mathrm{MgCl}_{2}$ and $\mathrm{CaCl}_{2}$ solutions are presented in Figure S4. From these spectra, the pyrene polarity ratio $I_{1} / I_{3}$ was calculated. The obtained values are reported in Table S8 and plotted as a function of temperature in Figure 4. The immediately evident feature of the spectra in Figure S4 is the decrease in fluorescence intensity with increasing temperature, which significantly distorts the spectrum for aPMA in $\mathrm{CaCl}_{2}$ solution at $95^{\circ} \mathrm{C}$. This is attributed to extensive precipitation of aPMA from this solution, as discussed above. No $I_{1} / I_{3}$ value is therefore reported for aPMA in $\mathrm{CaCl}_{2}$ at the highest temperature.

The most obvious result of Figure 4 is that $I_{1} / I_{3}$ values are higher in iPMA (above 1.4 in iPMA- $\mathrm{MgCl}_{2}$ and above 1.1 in iPMA- $\mathrm{CaCl}_{2}$ solutions) than in aPMA solutions (here $I_{1} / I_{3}$ values start at around 0.85 at low $T \mathrm{~s}$ ) and only weakly increase with temperature with no evident change of slope in the iPMA case. The value $I_{1} / I_{3} \approx 1.5$ in iPMA- $\mathrm{MgCl}_{2}$ solutions points to a rather high polarity of microenvironment where pyrene molecules reside in these solutions. For comparison, $I_{1} / I_{3}$ is 1.3 in methanol, 1.35 in ethyl acetate, and around 1.7 (depending on the presence of eventual ions) in water. ${ }^{33}$ These high $I_{1} / I_{3}$ values are attributed to strong interactions of $\mathrm{Mg}^{2+}$ ions with water molecules, due to which these cations bring a lot of water into the associates with iPMA. At the same time the monodentate binding of $\mathrm{Mg}^{2+}$ is weaker in comparison with cations that release the hydration water $\left(\right.$ like $\left.\mathrm{Ca}^{2+}\right) .{ }^{37}$ However, the iPMA $\left(\alpha_{N}=0.2\right)$ chains must be held rather strongly in these associates, considering that they are charged and thus also repel each other. As proposed previously ${ }^{28}$ we attribute the stability of the iPMA associates to strong cooperative intermolecular $\mathrm{H}$-bonds between unionized $\mathrm{COOH}$ groups on different iPMA chains and in case of $\mathrm{Mg}^{2+}$ ions also to $\mathrm{H}$-bonds between $\mathrm{COOH}$ groups and the hydration water molecules around the ion. The presence of large amounts of water in the iPMA- $\mathrm{MgCl}_{2}$ associates contributes to the observed high $I_{1} / I_{3}$ values.

The $I_{1} / I_{3}$ values for iPMA in $\mathrm{CaCl}_{2}$ are somewhat lower $\left(I_{1} / I_{3} \approx 1.1-1.3\right)$ than in $\mathrm{MgCl}_{2}$ solutions, which can be explained by bidentate $\mathrm{Ca}^{2+}$ binding to carboxylate groups. ${ }^{11,17-19}$ This type of binding is accompanied by elimination of water from cation's hydration sphere and thus also from the associates. Consequently, the polarity of these associates is determined mainly by $\mathrm{H}$-bonded $\mathrm{COOH}$ groups and is thus expected to be lower. Altogether, fluorescence measurements show that the interior of the iPMA associates is actually rather polar (in contrast to aPMA; see below) and stems from polar $\mathrm{COOH}$ groups and/or water in these associates. Strong H-bonding between $\mathrm{COOH}$ groups is facilitated by their suitable isotac- tic orientation on the iPMA chain. Meanwhile, the charged $\mathrm{COO}^{-}$groups are positioned on the surface and grant the solubility of the associates in water.

The pyrene polarity ratio in aPMA solutions at temperatures below $45{ }^{\circ} \mathrm{C}$ is $I_{1} / I_{3} \approx 0.85-0.95$ (irrespective of the cation) and demonstrates a considerably less polar microenvironment of the aPMA aggregates. This can be explained by so-called hydrophobic interactions that force the methyl groups to hide inside the cores of the aPMA aggregates, which is well known. The irregular orientation of $\mathrm{COOH}$ groups on aPMA actually facilitates the formation of such hydrophobic cores as a result of higher flexibility of the aPMA chain and at the same time does not allow extensive H-bonding (as in the iPMA case). The hydrophilic $\mathrm{COOH}$ groups are positioned mostly on the surface and protect the core against the water solvent. Above $45^{\circ} \mathrm{C}$, an increase is observed in $I_{1} / I_{3}$ values for aPMA solutions in both, $\mathrm{MgCl}_{2}$ and $\mathrm{CaCl}_{2}$, which is attributed to precipitation of aPMA aggregates from solutions. Some of the pyrene molecules remain accumulated inside these precipitates and are removed from water, whereas the remaining ones detect the polarity of water without aPMA.

The above conclusions apply also to higher $I$ values, however the increasing in $I$ has no significant effect on the $I_{1} / I_{3}$ ratio. Its value depends primarily on chain tacticity (see the $I_{1} / I_{3}$ values measured at $25{ }^{\circ} \mathrm{C}$ in Table S9).

\section{2. LS Characterization of aPMA and iPMA Associates at $25^{\circ} \mathrm{C}$}

Further structural information about the associates was obtained by LS measurements at $25^{\circ} \mathrm{C}$. In Table 1 , the $R_{\mathrm{h} \text {,ass }}, R_{\mathrm{g} \text {,ass }}$ and $\rho$ values are reported for aPMA $\left(\alpha_{\mathrm{N}}=0\right)$ and iPMA $\left(\alpha_{\mathrm{N}}=0.2\right)$ associates in $\mathrm{MgCl}_{2}$ and $\mathrm{CaCl}_{2}$ solutions. The $R_{\mathrm{h} \text {,ass }}$ values (the dynamic LS data) are shown in Figures $5 \mathrm{a}$ and $5 \mathrm{~b}$ as a function of $q^{2}$ ( $q$ is the scattering vector given by the relationship $q=\left(4 \pi n_{0} / \lambda_{0}\right) \sin (\theta / 2)$, with $n_{0}$ the refractive index of the medium and $\lambda_{0}$ the wavelength of the incident light). From these dependencies, the zero angle values were obtained by using either linear function or second order polynomial for extrapolation to $\theta$ $=0^{\circ}$. In Figures $5 \mathrm{c}$ and $5 \mathrm{~d}$, the static LS data are presented for both PMA isomers in the form of a Kratky plot (i.e. the dependence of $\left(q R_{\mathrm{g}}\right)^{2} P(\theta)$ on $\left.q R_{\mathrm{g}}\right)$ and compared with the calculated curves for some well-known particle topologies.

The DLS results show that aPMA particles in the presence of both divalent salts have more or less comparable hydrodynamic radii (160-190 nm). However, the radii of gyration (the SLS result) of these particles are considerably smaller in the presence of $\mathrm{Ca}^{2+}$ ions, leading to lower $\rho$ values in this case. The value $\rho \approx 0.70\left(\mathrm{aPMA}-\mathrm{CaCl}_{2}\right.$ with $I=0.1 \mathrm{~mol} \mathrm{~L}^{-1}$ ) indicates micro-gel like structure of particles with mass concentrated in the core surrounded by a water swollen corona, whereas $\rho \approx 0.90$ in both aPMA-Mg$\mathrm{Cl}_{2}$ solutions points to a more even mass distribution. For comparison, a homogeneous mass distribution, such as in 
Table 1. Hydrodynamic radii $\left(R_{\mathrm{h} \text {,ass }}\right)$, radii of gyration $\left(R_{\mathrm{g}, \text { ass }}\right)$ and parameter $\rho\left(=R_{\mathrm{g} \text {,ass }} / R_{\mathrm{h} \text {,ass }}\right)$ for associates of iPMA $\left(c_{\mathrm{p}}=0.022 \mathrm{~mol} \mathrm{~L} \mathrm{~L}^{-1}, \alpha_{\mathrm{N}}=0.20\right)$ and aPMA $\left(c_{\mathrm{p}}=0.023 \mathrm{~mol} \mathrm{~L}-1, \alpha_{\mathrm{N}}=0\right)$ in the presence of $\mathrm{MgCl}_{2}$ and $\mathrm{CaCl}_{2}$ at different $I$ and at $25^{\circ} \mathrm{C}$.

\begin{tabular}{|c|c|c|c|c|c|c|c|c|}
\hline \multirow[b]{2}{*}{ Added salt } & \multicolumn{4}{|c|}{ iPMA } & \multicolumn{4}{|c|}{ aPMA } \\
\hline & $I / \mathrm{mol} \mathrm{L}^{-1}$ & $R_{\mathrm{h}, \text { ass }} / \mathrm{nm}$ & $R_{\mathrm{g}, \text { ass }} / \mathrm{nm}$ & $\rho$ & $I / \mathrm{mol} \mathrm{L}^{-1}$ & $R_{\mathrm{h}, \text { ass }} / \mathrm{nm}$ & $R_{\mathrm{g}, \text { ass }} / \mathrm{nm}$ & $\rho$ \\
\hline \multirow[t]{2}{*}{$\mathrm{MgCl}_{2}$} & 0.01 & 75 & 73 & 0.97 & 0.1 & 178 & 164 & 0.92 \\
\hline & 0.02 & 177 & 180 & 1.02 & 0.2 & 191 & 160 & 0.84 \\
\hline \multirow[t]{2}{*}{$\mathrm{CaCl}_{2}$} & 0.01 & 65 & 76 & 1.16 & 0.1 & 161 & 109 & 0.68 \\
\hline & $0.02^{\mathrm{a})}$ & $111^{\mathrm{b})}$ & $153^{\mathrm{b})}$ & $1.37^{\mathrm{b})}$ & $0.2^{\mathrm{b})}$ & $178^{\mathrm{b})}$ & $125^{\mathrm{b})}$ & $0.70^{\mathrm{b})}$ \\
\hline
\end{tabular}

${ }^{\text {a) }} \alpha_{\mathrm{N}}=0.63 ;{ }^{\text {b) }}$ upper phase; ${ }^{\mathrm{c})}$ lower phase
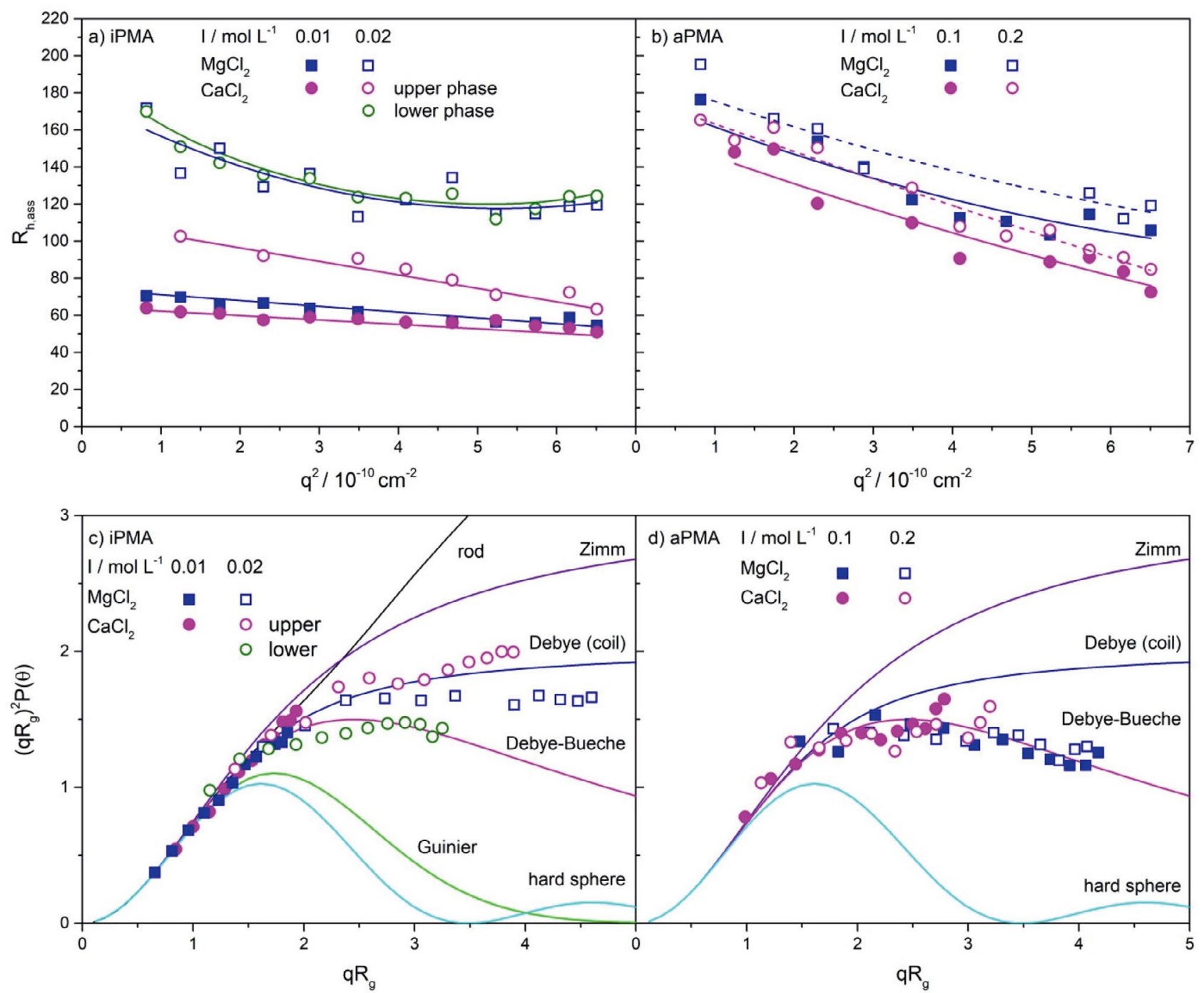

Figure 5. Hydrodynamic radii $\left(R_{\mathrm{h}, \text { ass }}\right)$ as a function of $q^{2}$ for a) iPMA $\left(c_{\mathrm{p}}=0.022 \mathrm{~mol} \mathrm{~L}^{-1}, \alpha_{\mathrm{N}}=0.20\right)$ in $\mathrm{MgCl}_{2}$ and $\mathrm{CaCl}_{2}$ with $I=0.01 \mathrm{~mol} \mathrm{~L}$ (full squares) and $I=0.02 \mathrm{~mol} \mathrm{~L}^{-1}$ (open symbols) (note that $\alpha_{\mathrm{N}}=0.63$ for iPMA in $\mathrm{CaCl}_{2}$ with $\left.I=0.02 \mathrm{~mol} \mathrm{~L}^{-1}\right)$ and for b) aPMA $\left(c_{\mathrm{p}}=0.023\right.$ mol L $\mathrm{L}^{-1}$, $\left.\alpha_{\mathrm{N}}=0\right)$ in the corresponding salt solutions with $I=0.1$ and $0.2 \mathrm{~mol} \mathrm{~L}^{-1}$. The Kratky plot (the dependence of $\left(q R_{\mathrm{g}}\right)^{2} P(\theta)$ on $\left.q R_{\mathrm{g}}\right)$ for selected topologies (solid lines; for details on these scattering functions see ${ }^{44}$ ) and the experimental data for $\mathrm{c}$ ) iPMA $\left(\alpha_{\mathrm{N}}=0.20\right.$ for all salt solutions, except for CaCl ${ }_{2}$ with $I=0.02 \mathrm{~mol} \mathrm{~L}^{-1}$ where $\left.\alpha_{\mathrm{N}}=0.63\right)$ and d) aPMA associates $\left(\alpha_{\mathrm{N}}=0\right)$ in aqueous solutions of $\mathrm{MgCl}_{2}$ and $\mathrm{CaCl}_{2}$ salt solutions with $I=0.1$ and 0.2 $\mathrm{mol} \mathrm{L}-1$.

a (monodisperse) hard sphere, would result in $\rho=0.778$. By considering that polydyspersity that is virtually always present in real samples tends to increase $\rho$, a particle with a measured $\rho$ of 0.70 definitely cannot be a hard sphere.
Lower $\rho$ values in the presence of $\mathrm{CaCl}_{2}$ are actually expected due to the preference of strong bidentate binding of $\mathrm{Ca}^{2+}$ to carboxylate groups as discussed above. $\mathrm{Ca}^{2+}$ ions release coordinated water molecules upon binding to car- 
boxylate groups, the aggregates' interior is thus 'drier' (leaving only the outer layers hydrated) and therefore more compact. On the other hand, $\mathrm{Mg}^{2+}$ ions remain strongly hydrated due to their pronounced inability to dehydrate and thus the aPMA chains in $\mathrm{MgCl}_{2}$ solutions form rather loose and more water swollen aggregates. Such environment offers more mobility to the chains and the structure is more permeable for the solvent, which altogether leads to higher $\rho$ values. Still, $\rho \approx 0.90$ for aP$\mathrm{MA}-\mathrm{MgCl}_{2}$ aggregates is far from values known for random coils of single chains in a $\theta$-solvent $(\rho \approx 1.5)$.

The Kratky plots for aPMA aggregates in both metal chlorides (Figure 5d) confirm the suggested structures. The data points coincide with the Debye-Bueche scattering function, which is valid for micro-gel like particles with a core-shell structure and at the same time demonstrate that the increase in $I$ does not greatly affect the structure, which is reasonable in case of aPMA $\left(\alpha_{N}=0\right)$ with charge close to zero. The experimental points for aPMA in $\mathrm{CaCl}_{2}$ solutions show a noticeable upturn from the Debye-Bueche towards the Debye scattering function at high $q R_{\mathrm{g}}$ values. This kind of upturns were previously attributed to the excluded-volume interactions, ${ }^{37,40}$ which may be more pronounced in case of $\mathrm{Ca}^{2+}$ ions in view of their stronger interaction with carboxyl groups. We actually demonstrate in the following (see results of $\mathrm{pH}$ measurements below), that $\mathrm{Ca}^{2+}$ ions replace some $\mathrm{H}^{+}$ions from $\mathrm{COOH}$ groups and thus increase the ionization of aPMA.

Different from aPMA, $R_{\mathrm{h} \text {,ass }}$ and $R_{\text {g,ass }}$ values for iPMA associates in $\mathrm{MgCl}_{2}$ and $\mathrm{CaCl}_{2}$ with lower $I(=0.01$ mol L ${ }^{-1}$ ) are significantly smaller in comparison to those in solutions with higher $I\left(=0.02 \mathrm{~mol} \mathrm{~L}^{-1}\right)$. This result is reasonable, because salt concentration should play a more important role in the case of partly charged iPMA $\left(\alpha_{\mathrm{N}}=\right.$ 0.2 ) chains: higher salt concentration (higher $I$ ) contributes to stronger electrostatic screening and enables more extensive intermolecular association and formation of larger particles. However, $\rho$ values for iPMA- $\mathrm{Mg}^{2+}$ associates are not much affected by $I(\rho \approx 1)$, whereas those for iPMA- $\mathrm{Ca}^{2+}$ associates range from 0.69 (the lower phase formed in the $\mathrm{CaCl}_{2}$ solution with $I=0.02 \mathrm{~mol} \mathrm{~L}^{-1}$ and $\alpha_{\mathrm{N}}$ $=0.63$; see Experimental Section) to 1.37 (the upper phase in the same solution). In the Kratky plot we see that the experimental data for larger particles in iPMA solutions show a systematic positive shift from the Debye-Bueche function at high $q R_{\mathrm{g}}$ values. We attribute these observations to a possibility that different structural elements are present in the iPMA-Ca ${ }^{2+}$ associates. Let's assume that the bidentate binding of $\mathrm{Ca}^{2+}$ proceeds predominately via bridging interaction with carboxyl groups on neighboring iPMA chains (i.e. intermolecularly), whereas the chelating (intramolecular) binding is less likely (see a scheme of both binding modes in Figure 6). The bridging bidentate binding with a concomitant pronounced dehydration of $\mathrm{Ca}^{2+}$ ions may induce structural elements of higher rigidity within these complexes, in particular considering also the isotacticty of the chain, and contributes to shifting of the points in the Kratky plot toward more rod-like structures. On the other hand, portions of the iPMA chains that are not involved in this complexation (presumably the more ionized parts) form coil-like outer regions with higher $\rho$ (c.f. $\rho=1.16$ and 1.37 for the homogeneous sample at $I=0.01 \mathrm{~mol} \mathrm{~L}^{-1}$ and for the upper phase at $I=0.02 \mathrm{~mol}$ $\mathrm{L}^{-1}$, respectively) around the compacted parts.

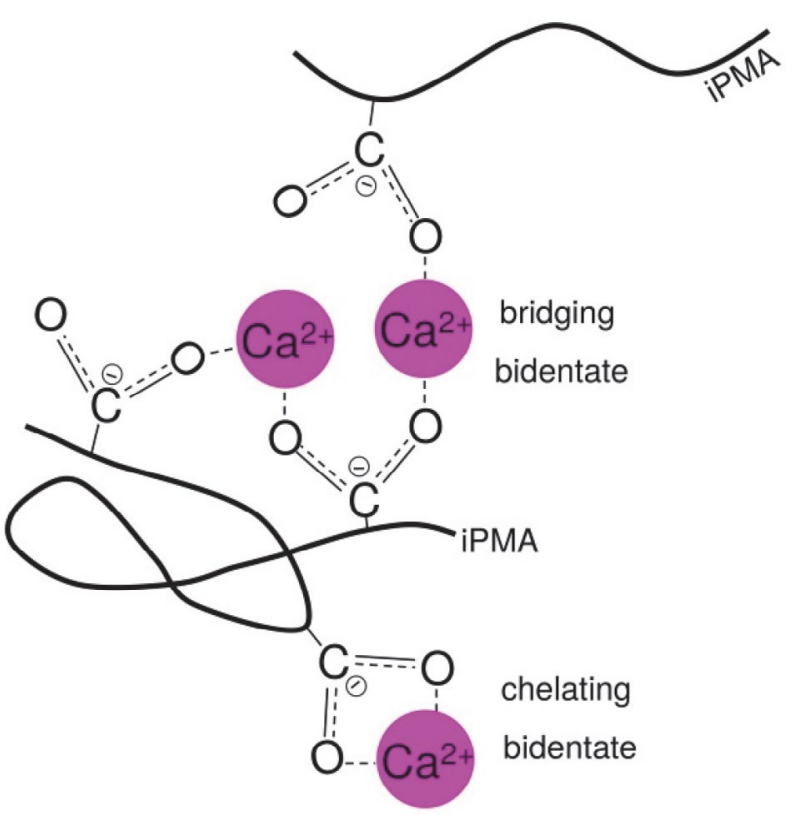

Figure 6. Cartoon depicting proposed ways of bidentate binding (chelate and bridging) of $\mathrm{Ca}^{2+}$ to $\mathrm{COO}^{-}$groups on iPMA chains.

At the end we should shortly comment also the result for the lower (polymer rich) phase in iPMA- $\mathrm{CaCl}_{2}$ solution with $I=0.02 \mathrm{~mol} \mathrm{~L}^{-1}$ and $\alpha_{\mathrm{N}}=0.63$ (note that these are average values for the whole sample). Here, $\rho$ (= 0.69 ) is again very low and the points in the Kratky plot fit the Debye-Bueche function, showing that associates in this phase are much more compact as compared to the upper more solvated and dilute phase. We also presume, that $\alpha_{N}$ in the bottom phase may be lower than the average value $\left(\alpha_{\mathrm{N}}=0.63\right)$.

We conclude the discussion of LS results by proposing that PMA-Ca ${ }^{2+}$ associates could also include interactions in terms of so-called egg-box model, commonly used in interpretation of gelation phenomena of alginates and pectates, which belong to a class of polysaccharides with carboxylate groups. ${ }^{7,9,10}$ According to the egg-box model, interaction between $\mathrm{COO}^{-}$groups on the polysaccharide and divalent cations is cooperative if the ion has an appropriate size to fit into the space in the egg-box, which is formed by the polyion backbone. $\mathrm{Ca}^{2+}$ fulfils this criterion, while the hydrated $\mathrm{Mg}^{2+}$ is too big. ${ }^{7}$ By proposing the existence of egg-box-like structural elements into which $\mathrm{Ca}^{2+}$ ions fit due to their size, one can understand both, the for- 
mation of more gel-like polymer-rich phase in aPMA-Ca$\mathrm{Cl}_{2}$ and more complex structural observations for iP$\mathrm{MA}-\mathrm{CaCl}_{2}$ solutions.

\section{2. 1. $\mathrm{pH}$ and Degree of Ionization}

In support of the above interpretation of differences between $\mathrm{MgCl}_{2}$ and $\mathrm{CaCl}_{2}$ solutions, we report the $\mathrm{pH}$ values for both PMA solutions, from which the degree of ionization $\left(\alpha_{\mathrm{i}}\right)$ of COOH groups was calculated from $\alpha_{\mathrm{i}}=\alpha_{\mathrm{N}}$ $+\left(\left[\mathrm{H}^{+}\right]-\left[\mathrm{OH}^{-}\right]\right) / c_{\mathrm{p}}$ (in this equation, $\left[\mathrm{H}^{+}\right]$and $\left[\mathrm{OH}^{-}\right]$are the molar hydronium and hydroxide concentrations). These measurements are reasonable only for aPMA solutions with $\alpha_{\mathrm{N}}=0$, because binding of cations has pronounced effect on ionization of COOH groups if $\alpha_{\mathrm{N}}=0$, whereas with iPMA with $\alpha_{\mathrm{N}}=0.2$ (or $\alpha_{\mathrm{N}}=0.63$ ) this effect is negligible (see the measured $\mathrm{pH}$ and calculated $\alpha_{\mathrm{i}}$ values in Table S10). The $\alpha_{i}$ values in aPMA solutions are plotted in Figure 7 as a function of $I$. Clearly, $\alpha_{\mathrm{i}}$ increases (from 0.013 at $I=0.1$ to 0.036 at $I=0.5 \mathrm{~mol} \mathrm{~L}^{-1}$ ) with increasing $I$ in aPMA-CaCl solutions, but changes negligibly in aP$\mathrm{MA}-\mathrm{MgCl}_{2}$ solutions. The pronounced (threefold) increase in the presence of $\mathrm{CaCl}_{2}$ is attributed to the replacement of $\mathrm{H}^{+}$cations from $\mathrm{COOH}$ groups upon bidentate binding of $\mathrm{Ca}^{2+}$ as predicted above. As a result, some $\mathrm{H}^{+}$ ions are released into the solution, $\mathrm{pH}$ decreases, and $\alpha_{\mathrm{i}}$ increases. On the contrary, the monodentate binding of $\mathrm{Mg}^{2+}$ ions to $\mathrm{COOH}$ groups is weaker and indirect (via hydration water molecules). $\mathrm{Mg}^{2+}$ is not able to replace $\mathrm{H}^{+}$ from the $\mathrm{COOH}$ group and has no (or negligible) effect on $\alpha_{\mathrm{i}}$. This clearly supports the above interpretations.

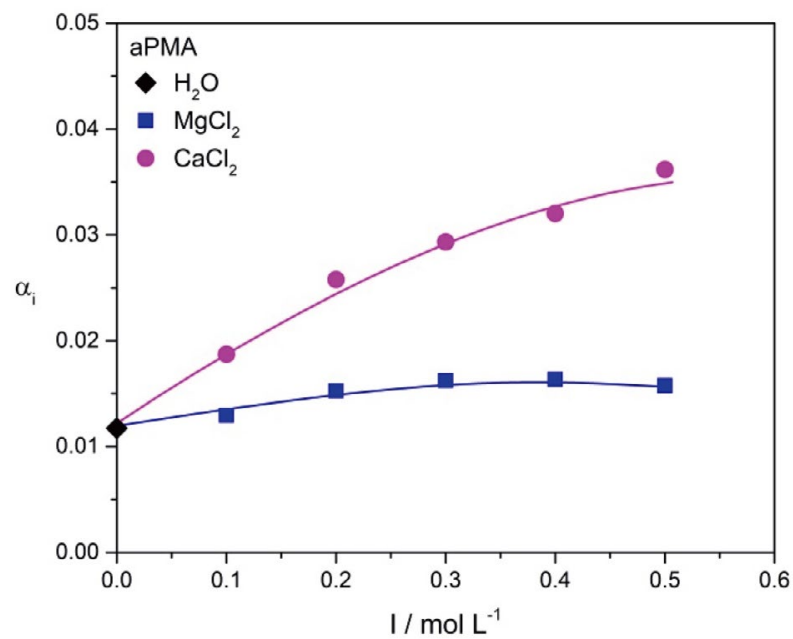

Figure 7. Calculated $\alpha_{\mathrm{i}}$ values for aPMA $\left(c_{\mathrm{p}}=0.023 \mathrm{~mol} \mathrm{~L}^{-1}, \alpha_{\mathrm{N}}=0\right)$ in dependence on $I$ in aqueous $\mathrm{MgCl}_{2}$ and $\mathrm{CaCl}_{2}$ solutions.

\section{Conclusions}

Our main interest in this study was the comparison of temperature induced intermolecular association in dilute aqueous solutions of two chemically identical PMA isomers, aPMA and iPMA, in the presence of divalent cations $\mathrm{Mg}^{2+}$ and $\mathrm{Ca}^{2+}$. UV spectroscopy and visual observations reveal that heating of aPMA solutions from 0 to 95 ${ }^{\circ} \mathrm{C}$ leads to intermolecular association and aggregate growth and finally to precipitation of aPMA from solution. Since the aPMA- $\mathrm{Mg}^{2+}$ and aPMA-Ca ${ }^{2+}$ precipitates re-dissolve upon cooling it was concluded that the process of association is reversible. Increasing $I$ in aPMA solutions (0.1-0.5 $\left.\mathrm{mol} \mathrm{L}^{-1}\right)$ leads to a decrease in the temperature at which phase separation occurs. iPMA behaves oppositely, which means that heating induces partial de-association of the aggregates, but the process is reversible and associates are reformed upon cooling. Nevertheless, iPMA- $\mathrm{Mg}^{2+}$ and iPMA-Ca ${ }^{2+}$ associates are stable in solution in the whole temperature range.

Considerable differences in micropolarity of the aPMA and iPMA aggregates in the presence of $\mathrm{Mg}^{2+}$ and $\mathrm{Ca}^{2+}$ ions are found by pyrene fluorescence measurements. The micropolarity of the iPMA associates is higher in comparison with the aPMA ones, which is attributed to different distribution of $\mathrm{CH}_{3}$ and $\mathrm{COOH}$ groups within the associates. It is proposed that the cores of iPMA associates are composed of $\mathrm{COOH}$ groups, connected via cooperative $\mathrm{H}$-bonds, in contrast to the aPMA ones where the $\mathrm{CH}_{3}$ groups reside in the aggregate interior. The polarity of the aggregates' interior in the iPMA- $\mathrm{MgCl}_{2}$ solutions is the highest and close to that of water due to strong hydration of $\mathrm{Mg}^{2+}$ ions.

The LS measurements in iPMA and aPMA solutions in $\mathrm{MgCl}_{2}$ and $\mathrm{CaCl}_{2}$ show that both PMAs form intermolecular associates with dimensions in the nanometer range at low $\alpha_{\mathrm{N}}$ values. The values of the shape parameter $\rho$ indicate either micro-gel like particles $(\rho \approx 0.7)$ or more water permeable structures $(\rho \approx 0.90)$ or even a combination of rod-like and coil-like regions in the same aggregate $(\rho \approx$ 1.37). This latter case was identified with iPMA aggregates in the presence of $\mathrm{Ca}^{2+}$ ions.

\section{Acknowledgements}

This work was financially supported by the Slovenian Research Agency (ARRS), through the Physical Chemistry program P1-0201.

ORCID - Ksenija Kogej: 0000-0002-6291-1032

\section{References}

1. T. Dudev, C. Lim, Chem. Rev. 2003, 103, 773-787. DOI:10.1021/cr020467n

2. M. Muthukumar, Macromolecules 2017, 50, 9528-9560. DOI:10.1021/acs.macromol.7b01929

3. F. Cilurzo, C. G. M. Gennari, F. Selmin, G. Vistoli, Mol. Pharm. 2010, 7, 421-430. DOI:10.1021/mp900199a

4. T. Dudev, C. Lim, Acc. Chem. Res. 2007, 40, 85-93. DOI:10.1021/ar068181i 
5. Schauss, F. Dahms, B. P. Fingerhut, T. Elsaesser, J. Phys. Chem. Lett. 2019, 10, 238-243. DOI:10.1021/acs.jpclett.8b03568

6. S. Kavitha, P. Deepa, M. Karthika, R. Kanakaraju, J. Mol. Graph. Model. 2018, 85, 13-24.

DOI:10.1016/j.jmgm.2018.07.004

7. J. Mattai, J. C. T. Kwak, J. Phys. Chem. 1984, 88, 2625-2629. DOI:10.1021/j150656a040

8. Y. Fang, S. Al-Assaf, G. O. Phillips, K. Nishinari, T. Funami, P. A. Williams, L. Li, J. Phys. Chem. B 2007, 111, 2456-2462. DOI:10.1021/jp0689870

9. X. Wang, H. G. Spencer, Polymer 1998, 39, 2759-2764. DOI:10.1016/S0032-3861(97)00597-1

10. L. Q. Wan, J. Jiang, D. E. Arnold, X. E. Guo, H. H. Lu, V. C. Mow, Cell. Mol. Bioeng. 2008, 1, 93-102.

DOI:10.1007/s12195-008-0014-x

11. J. Krebs, in: R. A. Mayers (Ed.): Encyclopedia of Molecular Cell Biology and Molecular Medicine, 2nd Edition, WileyVCH Verlag GmbH \& Co. KGaA, Weinheim, Germany, 2004, pp. 133-170.

12. A. Kaufman Katz, J. P. Glusker, S. A. Beebe, C. W. Bock, J. Am. Chem. Soc. 1996, 118, 5752-5763. DOI:10.1021/ja953943i

13. M. E. Maguire, J. A. Cowan, Biometals 2002, 15, 203-210. DOI:10.1023/A:1016058229972

14. W. Johnen-Dechent, M. Kettler, Clin. Kidney J. 2012, 5, i3i14. DOI:10.1093/ndtplus/sfr163

15. M. Eigen, Pure Appl. Chem. 1963, 6, 97-115. DOI:10.1351/pac196306010097

16. H. Diebler, M. Eigen, Pure Appl. Chem. 1969, 20, 93-116. DOI:10.1351/pac196920010093

17. T. Dudev, C. Lim, J. Phys. Chem. B 2004, 108, 4546-4557. DOI:10.1021/jp0310347

18. J. V. Needham, T.Y. Chen, J. J. Falke, Biochemistry 1993, 32, 3363-3367. DOI:10.1021/bi00064a020

19. R. Konradi, J. Rühe, Macromolecules 2004, 37, 6954-6961. DOI:10.1021/ma049126x

20. D. M. Chang, JAOCS, 1983, 60, 618-622. DOI:10.1007/BF02679800

21. A. Silberberg, J. Eliassaf, A. Katchalsky, J. Polym. Sci. 1957, 23, 259-284. DOI:10.1002/pol.1957.1202310325

22. M. Sedlák, Colloid Polym. Sci. 2017, 295, 1281-1292. DOI:10.1007/s00396-016-4003-7

23. M. Sedlák, Č. Konňák, Macromolecules 2009, 42, 7430-7438. DOI:10.1021/ma9015032

24. M. Sedlák, Č. Konňák, Macromolecules 2009, 42, 7439-7446. DOI:10.1021/ma901504h
25. A. K. Bajpai, S. K. Shukla, S. Bhanu, S. Kankane, Prog. Polym. Sci. 2008, 33, 1088-1118.

DOI:10.1016/j.progpolymsci.2008.07.005

26. K. Kogej, Polymers 2016, 8, 168. DOI: $10.3390 /$ polym 8050168

27. J. Eliassaf, A. Silberberg, Polymer 1962, 3, 555-564. DOI:10.1016/0032-3861(62)90103-9

28. P. Hriberšek, K. Kogej, Macromolecules, 2019, 52, 7028-7041. DOI:10.1021/acs.macromol.9b01467

29. E. Van den Bosch, Q. Keil, G. Filipcsei, H. Berghmans, H. Reynaers, Macromolecules 2004, 37, 9673-9675.

DOI: $10.1021 / \mathrm{ma} 047821 \mathrm{z}$

30. W. E. Goode, F. H. Owens, R. F. Fellmann, W. H. Snyder, J. E. Moore, J. Polym. Sci. 1960, 46, 317- 331.

DOI:10.1002/pol.1960.1204614803

31. B. Jerman, K. Kogej, Acta Chim. Slov. 2006, 53, 264-273.

32. K. Kogej, J. Škerjanc, Langmuir 1999, 15, 4251-4258. DOI:10.1021/la9811517

33. D. Y. Chu, J. K. Thomas, J. Am. Chem. Soc. 1986, 108, 6270-6276. DOI:10.1021/ja00280a026

34. E. M. Loebl, J. J. O’Niell, J. Polym. Sci. 1960, 45, 538-540. DOI:10.1002/pol.1960.1204514629

35. N. Vlachy, J. Dolenc, B. Jerman, K. Kogej, J. Phys. Chem. B 2006, 110, 9061-9071. DOI:10.1021/jp060422g

36. C. Urban, P. Schurtenberger, J. Colloid Interface Sci. 1998, 207, 150-158. DOI:10.1006/jcis.1998.5769

37. P. Hriberšek, K. Kogej, Polymers 2019, 11, 605. DOI:10.3390/polym11040605

38. S. Sitar, V. Aseyev, K. Kogej, Soft Matter 2014, 10, 7712-7722. DOI:10.1039/C4SM01448K

39. S. Sitar, V. Aseyev, K. Kogej, Polymer 2014, 55, 848-854. DOI:10.1016/j.polymer.2014.01.007

40. E. V. Tarassova, V. Aseyev, A. Filippov, H. Tenhu, Polymer 2007, 48, 4503-4510. DOI:10.1016/j.polymer.2007.05.069

41. H. G. Brittain, F. S. Richardson, R. B. Martin, J. Am. Chem. Soc. 1976, 98, 8255-8260. DOI:10.1021/ja00441a060

42. R. B. Martin, F. S. Richardson, Q. Rev. Biophys. 1979, 12, 181209. DOI:10.1017/S0033583500002754

43. C. G. Dos Remedios, Cell Calcium 1981, 2, 29-51. DOI:10.1016/0143-4160(81)90044-0

44. P. Kratochvil, in: M. B. Huglin (Ed.): Particle scattering functions in light scattering from polymer solutions, Academic Press Inc.: London and New York, 1972, pp. 333-384.

45. E. J. Robertson, A. P. Carpenter, C. M. Olson, R. K. Ciszewski, G. L. Richmond, J. Phys. Chem. C 2014, 118, 15260-15273. DOI:10.1021/jp503051w 


\section{Povzetek}

Z UV spektroskopijo, vizualnim opazovanjem in fluorimetrijo na osnovi pirena smo proučevali vpliv temperature na tvorbo asociatov med verigami izotaktične (iPMA) in ataktične poli(metakrilne kisline) (aPMA) v vodnih raztopinah $\mathrm{v}$ prisotnosti dvovalentnih kationov $\left(\mathrm{Mg}^{2+}\right.$ in $\left.\mathrm{Ca}^{2+}\right)$. Gretje raztopin aPMA povzroči agregacijo verig, kar vodi do makroskopske ločitve faz. $\mathrm{Z}$ naraščajočo ionsko jakostjo raztopin se nastop agregacije (segrevanje) oziroma de-agregacija (ohlajanje) aPMA verig pomika k nižjim temperaturam. Nasprotno pa asociati iPMA med segrevanjem razpadejo, a le delno, tako da so stabilni delci z nano-dimenzijami prisotni v raztopini v celotnem temperaturnem območju. Strukturno karakterizacijo agregatov smo izvedli z meritvami dinamičnega in statičnega sipanja svetlobe pri $25^{\circ} \mathrm{C}$. Rezultati kažejo, da agregati obeh PMA z $\mathrm{Mg}^{2+}$ vključujejo precej vode, porazdelitev mase znotraj delcev pa je precej enakomerna. To pripisujemo močni hidrataciji $\mathrm{Mg}^{2+}$ ionov, zaradi česar $\mathrm{Mg}^{2+}$ ioni favorizirajo monodentatno vezavo na karboksilatne skupine. $\mathrm{Ca}^{2+}$ ioni pa se vežejo nanje na bidentatni način in zato močneje kot $\mathrm{Mg}^{2+}$ ioni, pri čemer izgubijo hidratno vodo in tvorijo agregate $\mathrm{z}$ več strukturnimi elementi, kar je odvisno od taktičnosti verige. 